\title{
The Potential of Potassium Fertilizers in Improving the Availability and Uptake of Potassium in Rice Grown on Entisol
}

\author{
* Sri Hartati, Suryono and Lia Sari Purnama \\ Department of Soil Science, Faculty of Agriculture, Sebelas Maret University, Indonesia, \\ *e-mail: srihartati_tanahuns@yahoo.com
}

Received July 27, 2018; Revised March 28, 2019; Accepted April 1, 2019

\begin{abstract}
Entisol is a marginal soil spreading over some areas in Indonesia. It has loose soil consistency, low aggregation rates, sensitive to erosion, and low nutrient content. Entisol has high K deficiency. Potassium plays an important role in rice growth (Oryza sativa). The aim of the research was to study the effects of type and dose of potassium fertilizers on available $\mathrm{K}$ in Entisol and its uptake by rice plants. The study was arranged in a Randomized Complete Block Design with 2 factors, i.e. the types of potassium fertilizers $\left(\mathrm{KCl}, \mathrm{ZK}\right.$ and $\left.\mathrm{KNO}_{3}\right)$ and doses of potassium fertilizers $\left(0 \mathrm{~kg} \mathrm{~K}_{2} \mathrm{O} \mathrm{ha}^{-1}, 50 \mathrm{~kg} \mathrm{~K}_{2} \mathrm{O} \mathrm{ha}^{-1}, 100 \mathrm{~kg} \mathrm{~K}_{2} \mathrm{O} \mathrm{ha}^{-1}\right.$, and $\left.150 \mathrm{~kg} \mathrm{~K}_{2} \mathrm{O} \mathrm{ha}^{-1}\right)$, with three replications. The results showed that the type of potassium fertilizers applied resulted in similar effects on almost all soil and plant parameters. The dose of potassium fertilizers significantly affected all soil and plant parameters, the higher the doses, the higher the values of the parameters observed.
\end{abstract}

Keywords: Available K, K uptake, rice

\begin{abstract}
ABSTRAK
Entisol merupakan tanah marjinal yang tersebar di beberapa wilayah di Indonesia. Tanah ini memiliki konsistensi yang lemah, kemantapan agregat yang rendah, sensitif terhadap erosi dan kandungan unsur hara yang rendah. Entisol juga mengalami defisiensi unsur hara K yang tinggi. Kalium memiliki peranan penting pada pertumbuhan tanaman padi (Oryza sativa). Penelitian ini bertujuan untuk mempelajari pengaruh jenis dan dosis pupuk kalium terhadap K-tersedia pada tanah Entisol dan serapannya pada tanaman padi. Penelitian ini disusun dalam Rancangan Acak Kelompok Lengkap dengan 2 faktor, yaitu jenis pupuk kalium $\left(\mathrm{KCl}, \mathrm{ZK}, \mathrm{KNO}_{3}\right)$ dan dosis pupuk kalium $(0 \mathrm{~kg}$ $\mathrm{K}_{2} \mathrm{O} \mathrm{ha}^{-1}, 50 \mathrm{~kg} \mathrm{~K}_{2} \mathrm{O} \mathrm{ha}^{-1}, 100 \mathrm{~kg} \mathrm{~K}_{2} \mathrm{O} \mathrm{ha}^{-1}$, dan $150 \mathrm{~kg} \mathrm{~K}_{2} \mathrm{O} \mathrm{ha}^{-1}$ ), dengan tiga ulangan. Hasil penelitian menunjukkan bahwa jenis pupuk kalium yang diaplikasikan memberikan pengaruh yang sama terhadap hampir seluruh parameter tanah dan tanaman yang diukur dalam penelitian ini. Dosis pupuk kalium secara signifikan mempengaruhi semua parameter tanah dan tanaman, semakin tinggi dosis pupuk, semakin tinggi nilai dari masing-masing parameter yang terukur.
\end{abstract}

Kata kunci: K-tersedia, padi, serapan K

\section{INTRODUCTION}

Entisol is a marginal soil that is mainly distributed in Java, Sumatra and Nusa Tenggara covering an area of approximately 3 million ha or around $2.1 \%$ of the total land in Indonesia (Sarief 1986). Entisol is very young soil type and just experiences the begining of the development, so it has not formed a clear horizon layer. Nutrient availability in Entisol is determined by type of parent

J Trop Soils, Vol. 24, No. 2, 2019: 83-91

ISSN 0852-257X ; E-ISSN 2086-6682 materials in which some of nutrient elements are still attached in the parent materials. The potassium containing minerals in this soil have not experienced weathering so that the potassium availability is low (Arifin 2011). Utami and Handayani (2003) showed that Entisol has loose soil consistency, low aggregation rates, low nutrient content and very sensitive to erosion. Entisol has a very high deficiency of potassium due to it is easy to leach.

There are three forms of potassium in soil, namely: (1) potassium in the form of primary minerals, including feldspar, mica, biotite, etc. that is relatively unavailable (90-98\% of $\mathrm{K}$ total), (2) 
potassium that is fixed by secondary minerals, in the form of slowly available potassium (1-10\% of total K), (3) exchangeable potassium and potassium ions in soil solution ( $1-2 \%$ of total $\mathrm{K})$. The potassium that cannot be exchanged will become interchangeable-K and $\mathrm{K}$ present in soil solution that can be absorbed by plants (Damanik et al. 2011).

Potassium plays an important role in spurring assimilate translocation to the storage organs and regulating the opening and clossing of stomata. Potassium deficiency can inhibit the process of photosynthesis, metabolism and translocation of carbohydrates from leaves into grains, as a result, decreasing yield. The application of potassium fertilizer can increase rice yield (Singh et al. 2013). According to Jifu et al. (2014), $\mathrm{K}$ is the main limiting factor in rice growth. Potassium has an important role in rice cultivation. The potassium element that is easily leached from soil can result in deficiency in rice plants. Imbalances and limited use of $K$ resulted in the weakening of rice plant stems (Zaman et al. 2015) and small grains (Prajapati and Modi 2012).

The aim of the research was to study the effects of type and dose of potassium fertilizers on $\mathrm{K}$ availability in Entisol and its uptake by rice plants.

\section{MATERIALS AND METHOD}

\section{Research Design}

This study was conducted at paddy fields with Entisol soil type, located in Nglarang, Basin Village, Kebonarum Sub-district, Klaten Regency from April to November 2016. The soil and plant sample analyses were carried out at Soil Chemistry and Soil Fertility Laboratory, Faculty of Agriculture, Sebelas Maret University. The materials used include Urea fertilizer, SP-36 fertilizer, $\mathrm{KCl}$ fertilizer, ZK fertilizer, $\mathrm{KNO}_{3}$ fertilizer, rice seeds variety IR-64, and chemical substances for laboratory analyses. The study was arranged in a Randomized Complete Block Design (RCBD) with 2 factors, i.e. the types of potassium fertilizers and their doses. The types of potassium fertilizers included $\mathrm{KCl}, \mathrm{ZK}$, and $\mathrm{KNO}_{3}$. The doses of potassium fertilizers were $0 \mathrm{~kg} \mathrm{~K}_{2} \mathrm{O}$ ha-1 (without fertilizer), $50 \mathrm{~kg} \mathrm{~K}_{2} \mathrm{O} \mathrm{ha}^{-1}, 100 \mathrm{~kg} \mathrm{~K}_{2} \mathrm{O}$ $\mathrm{ha}^{-1}$, and $150 \mathrm{~kg} \mathrm{~K}_{2} \mathrm{O} \mathrm{ha}{ }^{-1}$. Therefore, there were 12 treatment combinations with 3 replications to obtain 36 plots.

\section{Soil Tillage and Rice Planting}

The soil of the paddy field was ploughed until it became loose, then leveled and set up into 3 blocks in the perpendicular direction according to its fertility level. Each block was divided into 12 plots. The size of each plot was $2 \mathrm{~m} \times 2.5 \mathrm{~m}$. The distance between each plot was $25 \mathrm{~cm}$ and the distance between each block was $50 \mathrm{~cm}$. After completing the soil tillage and plots, the rice plant seedlings with the age of \pm 18 days were planted with a spacing of $25 \mathrm{~cm} \times 25$ $\mathrm{cm}$, in which each planting point was planted with 5 seedlings.

\section{Plant Nurturing}

Irrigation of rice plants was conducted every day until the age of plants was 3 weeks, and every 3 days after the age of plants was more than 3 weeks, with inundation height of $\pm 5 \mathrm{~cm}$ from the soil surface. Fertilizers consisting of $400 \mathrm{~kg}$ Urea $\mathrm{ha}^{-1}$ and $300 \mathrm{~kg}$ SP-36 ha- ${ }^{-1}$ were applied. Potassium fertilizer was applied at planting according to the treatments.

\section{Soil Analysis}

Soil samples were taken before rice planting. The composite soil sample was taken from 5 points diagonally and then mixed into a homogenous soil sample. The initial soil characteristics were analyzed including texture (pippete method), particle density and bulk density (gravimetric method), organic matter content (Walkley and Black method), $\mathrm{pH}$ (electrometric method with the soil:water ratio 2:5), cation exchange capacity (CEC), base saturation and available- $\mathrm{K}\left(\mathrm{NH}_{4} \mathrm{OAc} \mathrm{pH}\right.$ 7), total-N (Kjeldhal method), and available-P (Bray 1 method).

Plant parameters were measured including plant height, dry weight of biomass, $\mathrm{K}$ tissue, and $\mathrm{K}$ uptake. Five clumps of plant samples were taken in each treatment plot. The plant samples were taken at the maximum vegetative growth indicated by the presence of panicles. All parts of the plants were dried at $70{ }^{\circ} \mathrm{C}$, weighed (dry weight of biomass) and milled for K-tissue analysis. The amount of $\mathrm{K}$ uptake by rice plants was calculated using the following formula: $\mathrm{K}$ uptake $=\mathrm{K}$ tissue $\times$ dry weight of biomass.

The soil samples were also taken after the maximum vegetative growth of rice plants. The soil samples were taken diagonally from 5 points in each treatment plot, then mixed to get homogenous soil samples. The soil samples were analyzed for Cation Exchange Capacity (CEC), Base Saturation and available $\mathrm{K}\left(\mathrm{NH}_{4} \mathrm{OAc} \mathrm{pH}\right.$ 7). The amount of available $\mathrm{K}$ in the soil samples taken after harvest was also determined.

\section{Data Analysis}

The data were analyzed using Analysis of Variance and continued with Duncan's Multiple 
Table 1.Physical and chemical properties of the soil before the experiment.

\begin{tabular}{llll}
\hline Parameter & Unit & Value & Criteria* \\
\hline Texture: & & & Sandy loam \\
$\quad$ Sand & $\%$ & 70.80 & \\
\multicolumn{1}{c}{ Silt } & $\%$ & 20.80 & - \\
$\quad$ Clay & $\%$ & 8.40 & \\
Particle density & $\mathrm{g} \mathrm{cm}^{-3}$ & 2.10 & - \\
Bulk density & $\mathrm{g} \mathrm{cm}^{-3}$ & 1.65 & - \\
Organic matter & $\%$ & 1.21 & Low \\
pH $\mathrm{H}_{2} \mathrm{O}$ & & 6.84 & Neutral \\
$\mathrm{CEC}$ & $\mathrm{Cmol}(+) \mathrm{kg}^{-1}$ & 23.41 & Moderate \\
Base Saturation & $\%$ & 16.04 & Very low \\
Total-N & $\%$ & 0.27 & Moderate \\
Available-P & $\mathrm{ppm}$ & 4.4 & Very low \\
Available- $\mathrm{K}$ & $\mathrm{Cmol}(+) \mathrm{kg}^{-1}$ & 0.06 & Very low \\
\hline
\end{tabular}

Note: * Criteria according to Eviati and Sulaeman (2009).

Range Test at 5\% significance level. The correlation tests between soil and plant parameters were also performed.

\section{RESULTS AND DISCUSSION}

\section{Initial Soil Properties}

Table 1 showed that the Entisol used in the current study has a sandy loam texture, which consists of $70.8 \%$ sand, $20.8 \%$ silt and $8.4 \%$ clay. The soil contains predominantly sand fraction than any other soil fractions. It causes the ability of soil in binding water is quite low and the nutrients are easily leached from the soil. The soil has a bulk density of $1.65 \mathrm{~g} \mathrm{~cm}^{-3}$ and particle density of $2.1 \mathrm{~g}$

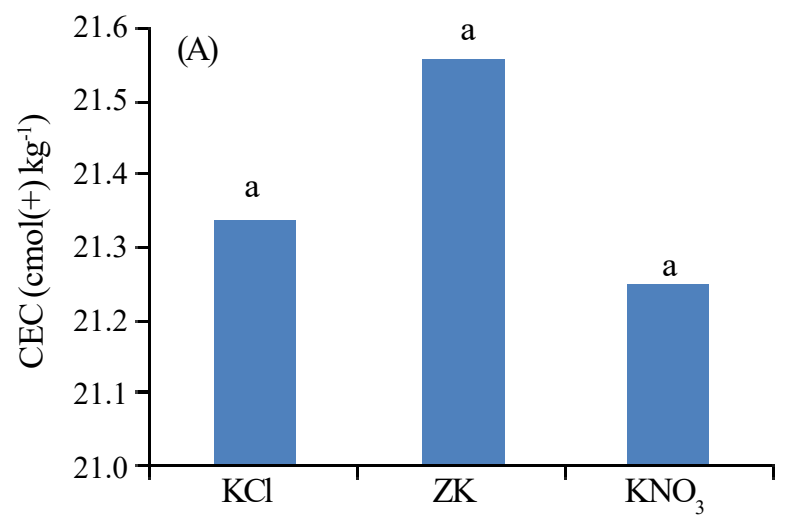

Type of Potassium Fertilizer $\mathrm{cm}^{-3}$. The values of bulk density and particle density indicate the magnitude of the soil porosity. The soil dominated by sand fraction has high bulk density and particle density, and has more macro pores than micro pores. The magnitude of soil porosity value shows the magnitude of its ability to bind water. The initial soil characteristics showed that the fertility level of soil in Kebonarum district, Klaten regency is quite low with moderate cation exchange capacity (CEC), i.e. $23.41 \mathrm{cmol}^{(+)} \mathrm{kg}^{-1}$ and low organic matter content, i.e. $1.21 \%$. The total $\mathrm{N}$ content, and available-P and -K are very low, namely $0.27 \%, 4.4$ $\mathrm{ppm}$, and $0.06 \mathrm{cmol}(+) \mathrm{kg}^{-1}$, respectively. The base saturation is $16.04 \%$, classified as very low and the $\mathrm{pH}$ is neutral (6.8). These results are in accordance with Utami's (2009), which indicated that Entisol or

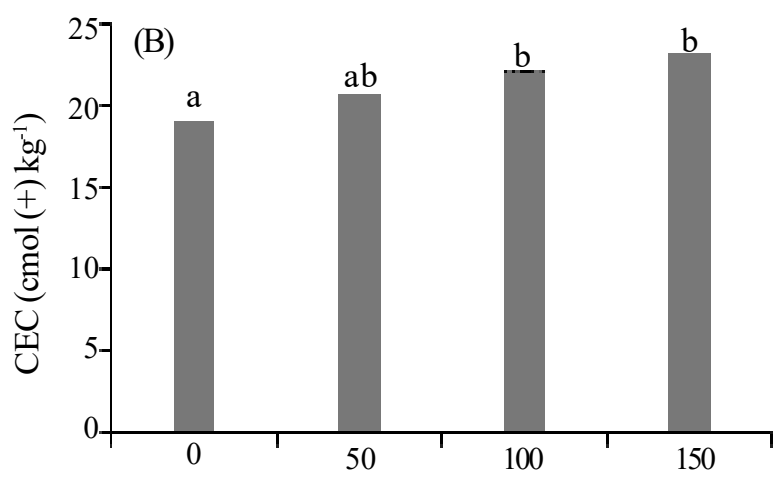

Dose of Potassium Fertilizer $\left(\mathrm{kg} \mathrm{K}_{2} \mathrm{O} \mathrm{ha}^{-1}\right)$

Figure 1. (A) The effects of the types of potassium fertilizers on CEC; (B) The effects of the doses of potassium fertilizers on CEC. The same letters above the bars show no significant difference according to DMRT at 5\% significance level. 


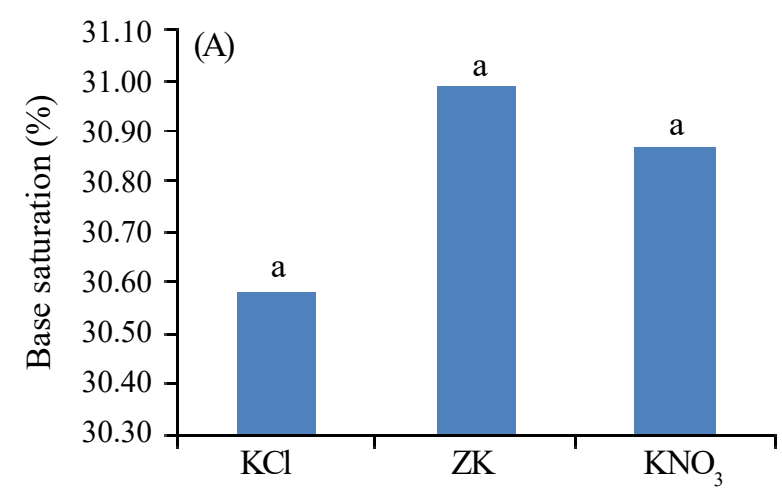

Type of Potassium Fertilizer

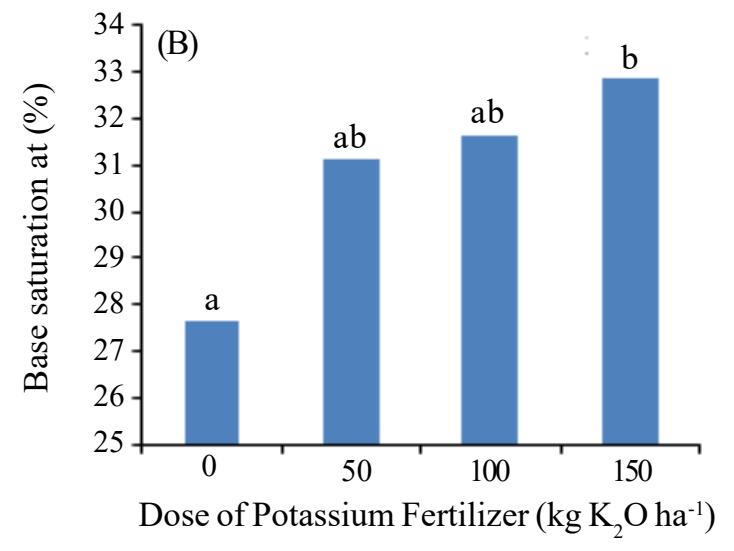

Figure 2. (A) The effects of the types of potassium fertilizers on base saturation; (B) The effects of the doses of potassium fertilizers on base saturation. The same letters above the bars show no significant difference according to DMRT at 5\% significance level.

Regosol has a coarse soil texture, with weak to loose soil aggregates or generally has not formed aggregate, inducing it to be easily exposed to erosion, and the soil $\mathrm{pH}$ is about $6-7$.

\section{Cation Exchange Capacity (CEC)}

Cation exchange capacity is defined as the amount of negative charge on soil colloids, which is expressed as the negative charge per unit mass of soil. The cation exchange capacity is an important factor that can affect plant nutrient avalaibility (Tisdale et al. 1985). The results of Analysis of Variance showed that the applications of types of potassium fertilizers showed no significant effect on CEC ( $p=0.81)$, whereas the doses of potassium fertilizers showed a significant effect on CEC ( $p=$ $0.01)$. The results of DMRT show that the effects of types of potassium fertilizers on CEC were not

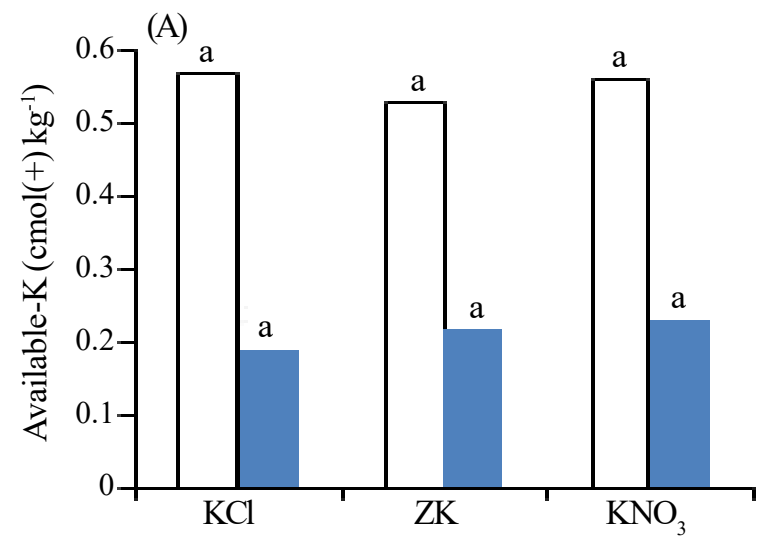

Type of Potassium Fertilizer significantly different among $\mathrm{KCl}, \mathrm{ZK}$ and $\mathrm{KNO}_{3}$ fertilizers (Figure 1a). Figure $1 \mathrm{~b}$ shows that the doses of potassium fertilizers significantly affected the CEC. The lowest CEC was measured in the soil without potassium fertilizer application, i.e. 19.11 cmol(+) $\mathrm{kg}^{-1}$ and the highest CEC was measured after application of $150 \mathrm{~kg} \mathrm{~K}_{2} \mathrm{O} \mathrm{ha}^{-1}$, i.e. $23.31 \mathrm{cmol}$ $(+) \mathrm{kg}^{-1}$. The soil CEC in the application of potassium fertilizers at $0 \mathrm{~kg} \mathrm{~K}_{2} \mathrm{O}$ ha $^{-1}$ showed no significantly different from that at $50 \mathrm{~kg} \mathrm{~K}_{2} \mathrm{O} \mathrm{ha}^{-1}$, but significantly different from that at $100 \mathrm{~kg} \mathrm{~K}_{2} \mathrm{O} \mathrm{ha}^{-1}$ and $50 \mathrm{~kg}$ $\mathrm{K}_{2} \mathrm{O} \mathrm{ha}^{-1}$. The higher the dose of potassium fertilizer applied, the higher the soil CEC is.

The results of the correlation test showed that the soil CEC is positively correlated to available-K both at the maximum vegetative growth of rice plants $(\mathrm{r}=0.39, p=0.02)$ and after harvest $(\mathrm{r}=$ $0.42, p=0.01$ ) (Table 3 ). The CEC is also positively

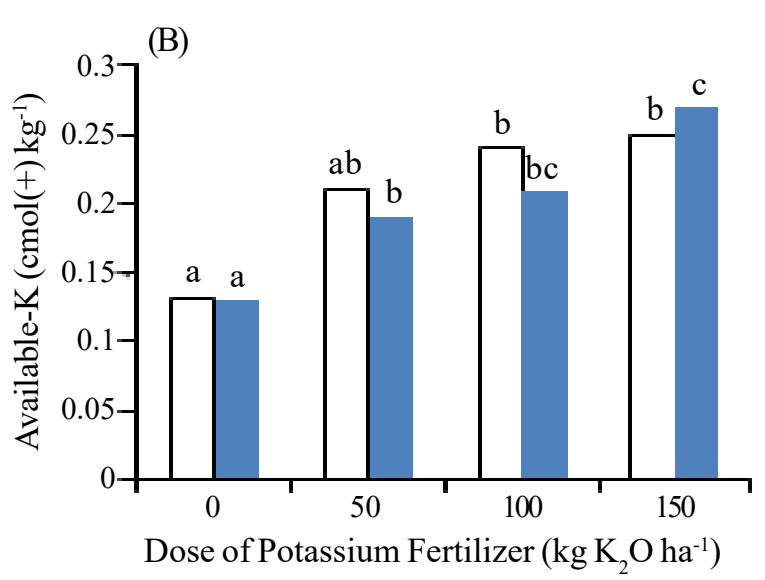

Figure 3. (A) The effects of the types of potassium fertilizers on available-K; (B) The effects of the doses of potassium fertilizers on available-K. The same letters above the bars show no significant difference according to DMRT at 5\% significance level. $\square$ : maximum vegetative growth; $\approx$ : after harvest 


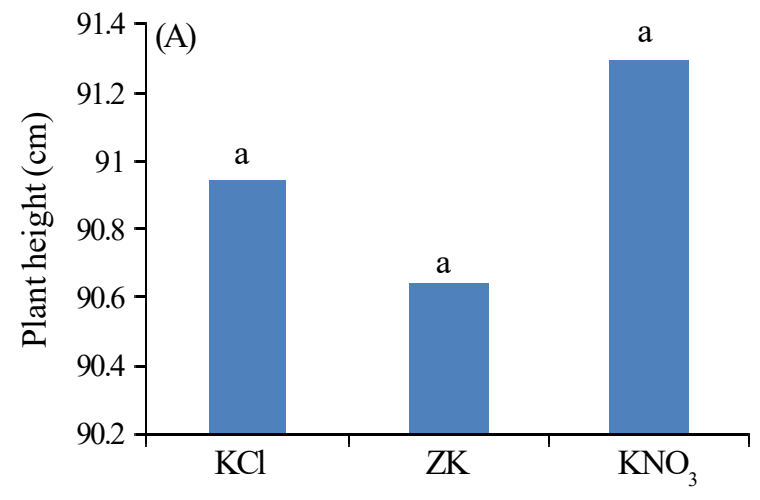

Type of Potassium Fertilizer

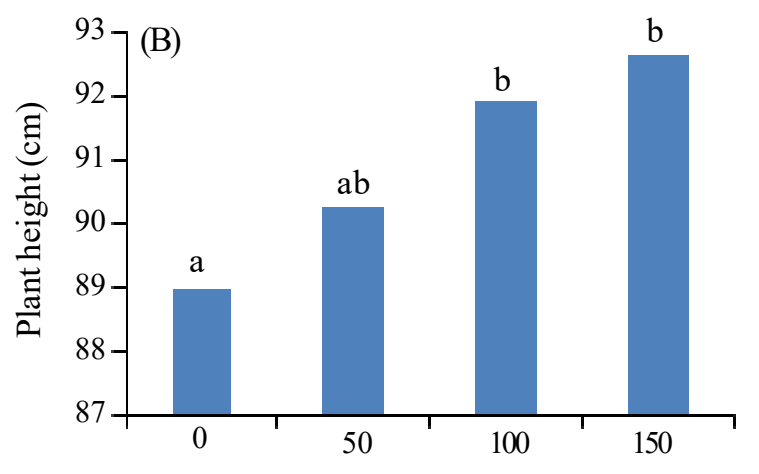

Dose of Potassium Fertilizer $\left(\mathrm{kg} \mathrm{K}_{2} \mathrm{O} \mathrm{ha}^{-1}\right)$

Figure 4. (A) The effects of the types of potassium fertilizers on plant height; (B) The effects of the doses of potassium fertilizers on plant height. The same letters above the bars show no significant difference according to DMRT at 5\% significance level.

correlated to $\mathrm{K}$-uptake by rice plants $(\mathrm{r}=0.57, p=$ 0.000). The high soil CEC causes the increase of cation exchange, so that the plant is able to absorb more $\mathrm{K}$ than at low soil CEC.

\section{Base saturation}

The ratio of the amount of base cations $(\mathrm{Ca}$, $\mathrm{Mg}, \mathrm{Na}$ and $\mathrm{K}$ ) to the amount of cations that can be exchanged (CEC) on soil colloids is called base saturation. The results of Analysis of Variance indicated that the types of potassium fertilizers applied showed no significant effect on base saturation ( $p=0.81$ ) (Figure 2a), whereas doses of potassium fertilizers resulted in a significant effect on base saturation ( $p=0.05$ ) (Figure $2 b$ ). The results of DMRT showed that the soil base saturation in the application of potassium fertilizers at $0 \mathrm{~kg} \mathrm{~K}_{2} \mathrm{O}$ $\mathrm{ha}^{-1}$ showed no significantly different from that at
$50 \mathrm{~kg} \mathrm{~K}_{2} \mathrm{O} \mathrm{ha}^{-1}$ and $100 \mathrm{~kg} \mathrm{~K}_{2} \mathrm{O}$ ha $^{-1}$ (Figure 2b). However, the soil base saturation in all the three treatments were significantly different from that at $150 \mathrm{~kg} \mathrm{~K} \mathrm{O} \mathrm{ha}^{-1}$, in which the base saturation reached $32.84 \%$. This result indicates that the increase of potassium fertilizer dose can increase soil base saturation. The increase of base saturation is due to the addition of $\mathrm{K}$ cations from the fertilizers.

\section{Available-K}

Available $\mathrm{K}$ is $\mathrm{K}$ that can be absorbed by plants in the form of $\mathrm{K}^{+}$ion. Potassium $(\mathrm{K})$ can be absorbed by plants in an exchangeable form and dissolved in soil solution. The results of Analysis Variance showed that the application of types of potassium fertilizers had no significant effect on the amount of available-K both at maximum vegetative growth of rice plants $(p=0.69)$ and after harvest $(p=0.87)$

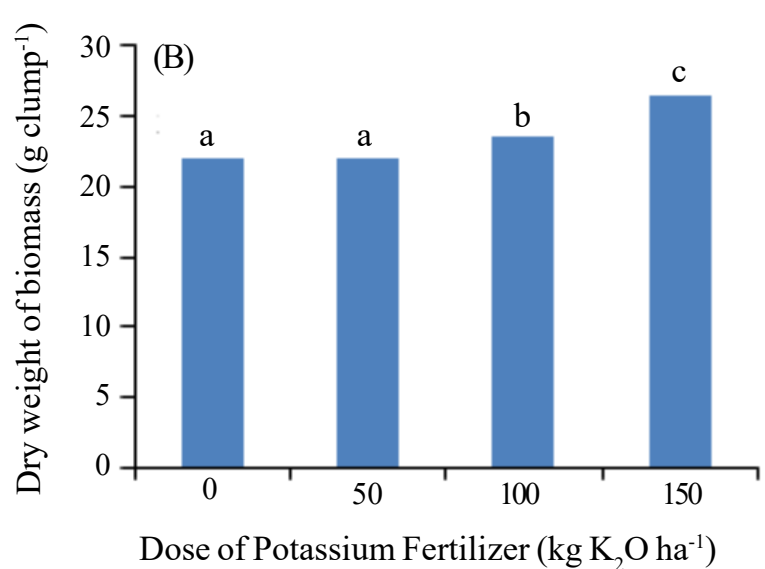

Figure 5. (A) The effects of the types of potassium fertilizers on dry weight of biomass; (B) The effects of the doses of potassium fertilizers on dry weight of biomass. The same letters above the bars show no significant difference according to DMRT at 5\% significance level. 


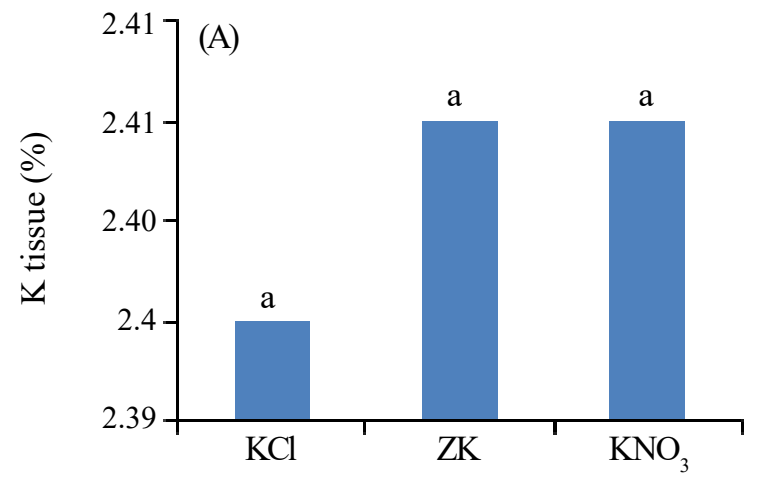

Type of Potassium Fertilizer

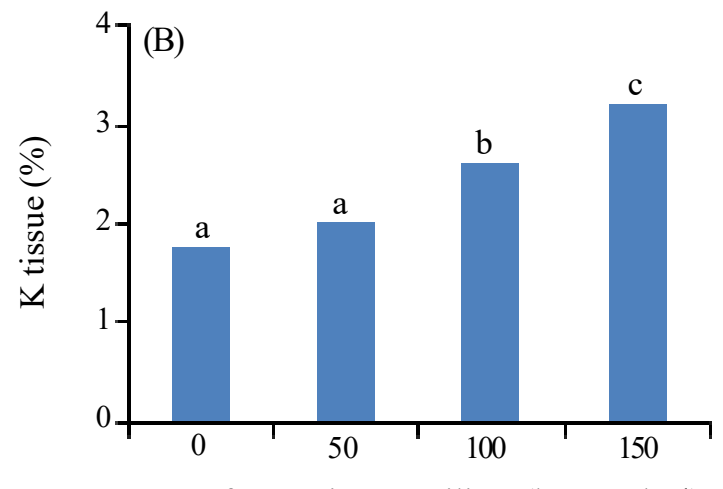

Dose of Potassium Fertilizer $\left(\mathrm{kg} \mathrm{K}_{2} \mathrm{O} \mathrm{ha}^{-1}\right)$

Figure 6. (A) The effects of the types of potassium fertilizers on K-tissue; (B) The effects of the doses of potassium fertilizers on K-tissue. The same letters above the bars show no significant difference according to DMRT at 5\% significance level.

(Figure 3a), whereas the dose of potassium fertilizers resulted in a significant effect on the amount of available- $\mathrm{K}$ at vegetative growth $(p=$ $0.02)$ and after harvest $(p=0.001)$ (Figure 3b). The higher the dose of fertilizers applied, the higher the amount of available-K for plant uptake is. The results of DMRT indicated that the amount of available-K in the soil whithout potassium fertilizer application showed no significantly different from that in the application of $100 \mathrm{~kg} \mathrm{~K}_{2} \mathrm{O} \mathrm{ha}{ }^{-1}$, especially at maximum vegetative growth (Figure $3 b$ ). The application of $100 \mathrm{~kg} \mathrm{~K}_{2} \mathrm{O} \mathrm{ha}^{-1}$ resulted in no significantly different on the amount of available- $\mathrm{K}$ compared to that at $150 \mathrm{~kg} \mathrm{~K}_{2} \mathrm{O} \mathrm{ha}^{-1}$. The increase of potassium fertilizer dose is proportional to the increase of available-K in the soil, especially at the maximum vegetative growth of rice plants.

The potassium fertilizers of $\mathrm{KCl}, \mathrm{ZK}$ and $\mathrm{KNO}_{3}$ after being put into the soil will experience ionization by water. The result of ionization will increase $\mathrm{K}^{+}$concentration, and subsequently the $\mathrm{K}$ ion in soil solution will be easily absorbed by plants. The results of correlation analysis shows that the amount of available- $\mathrm{K}$ in soil is positively correlated to plant height $(\mathrm{r}=0.35 ; p=0.036), \mathrm{K}-$ tissue $(\mathrm{r}=0.51 ; p=0.002)$ and $\mathrm{K}$-uptake $(\mathrm{r}=0.39$ and $p=0.02$ ) (Table 3 ).

\section{Plant Height}

The measurement of plant height was carried out at 8 weeks after planting. The results of Analysis Variance shows that the types of potassium fertilizers applied showed no significant effect on plant height $(p=0.065)$ (Figure 4a), whereas the doses of potassium fertilizers showed a significant effect on plant height $(p=0.028)$ (Figure $4 \mathrm{~b})$. The results of DMRT indicated that the plant height in the treatment of potassium fertilizers at $0 \mathrm{~kg} \mathrm{ha}^{-1} \mathrm{~K}_{2} \mathrm{O}$ was not significantly different from that at $50 \mathrm{~kg} \mathrm{ha}^{-1} \mathrm{~K}_{2} \mathrm{O}$ (Figure 4b). The highest plant height of $92.66 \mathrm{~cm}$ was measured in the application of $150 \mathrm{~kg} \mathrm{~K} \mathrm{O}$ $\mathrm{ha}^{-1}$. It was not significantly different from that in the treatment of $100 \mathrm{~kg} \mathrm{~K}_{2} \mathrm{O} \mathrm{ha}^{-1}$, i.e. $91.92 \mathrm{~cm}$.

The plant height is correlated to the amount of available- $\mathrm{K}$ measured at maximum vegetative growth $(\mathrm{r}=0.35, p=0.036)$ and after harvest $(\mathrm{r}=$ $0.41, p=0.01)$. This result shows that the plant height is largely determined by the availability of $\mathrm{K}$ in the soil. Fitriadi et al. (2012) indicated that potassium plays a role in photo-phosphorylation in photosynthesis and can increase plant height. According to Marchner (1986), potassium plays a role in plant growth because it helps carbohydrate metabolism and accelerates the growth of meristematic tissue. Potassium stimulates the assimilate translocation to the storage organs and regulates the opening and closing of stomata. Orcutt and Nilsen (2000) showed that potassium can support leaf formation and increase stomata resistance. This will have an impact on increasing the amount of $\mathrm{CO}_{2}$ that diffuses into the plant, so the phytosynthesis rate increases.

\section{Dry Weight of Biomass}

The results of Analysis of Variance indicated that the types and doses of potasssium fertilizers showed significant effects on dry weight of biomass ( $p=0.03$ and 0.047 , respectively). The results of DMRT showed that the application of $\mathrm{KCl}$ and $\mathrm{ZK}$ fertilizers resulted in no significant difference on dry weight of biomass, but $\mathrm{KNO}_{3}$ fertilizer resulted in the highest dry weight of biomass, i.e. $25.84 \mathrm{~g}$ clump $^{-1}$ (Figure 5a). According to Syarif et al. (2013), biomass weight can be affected by the 

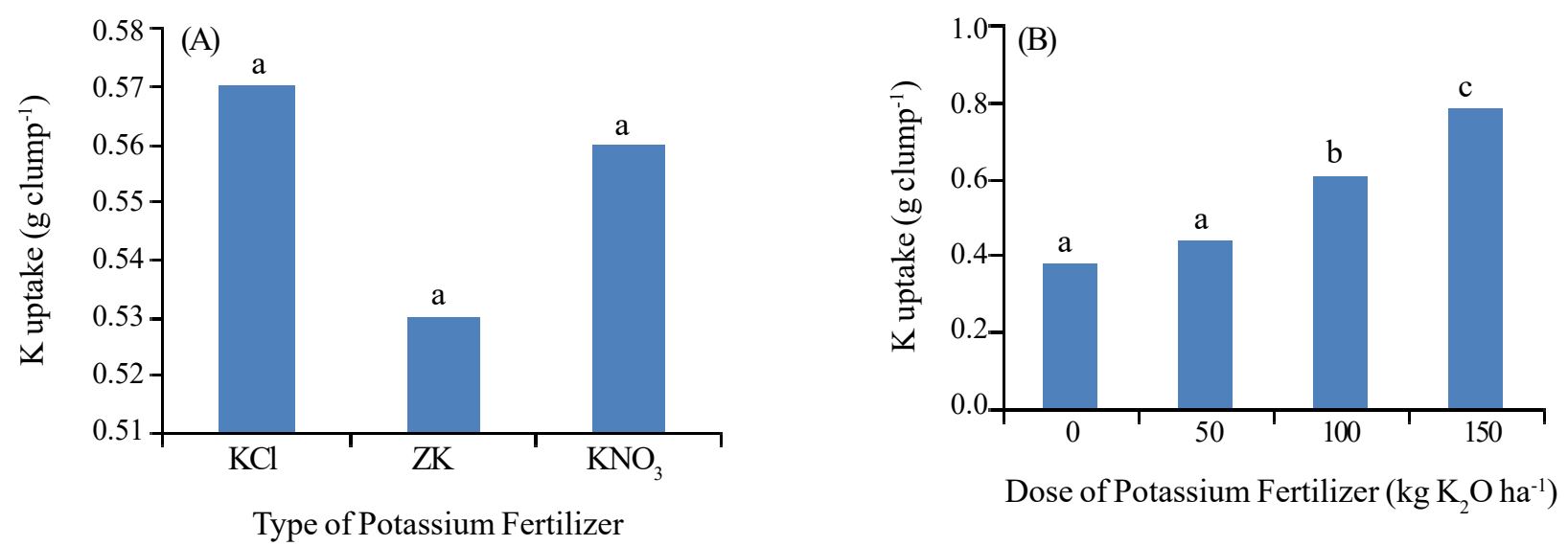

Figure 7. (A) The effectof the type of fertilizer to K uptake; (B) The effect of the dose of fertilizer to K uptake. Description: The numbers followed by the same letter show no significan difference at the level 0.05 with DMRT.

uptake of N, P, K and water by plants. Nitrogen can stimulate vegetative growth (leaves and stems) and increase the number of tiller and clump (Sudarsono 2004).

The results of DMRT show that the dry weight of biomass without potassium fertilizer application was about $21.91 \mathrm{~g} \mathrm{clump}^{-1}$, which was not significantly different from that in the application of $50 \mathrm{~kg} \mathrm{~K}_{2} \mathrm{O} \mathrm{ha}^{-1}$ (Figure 5b). However, the dry weight of biomass in both treatments were significantly different from that at $100 \mathrm{~kg} \mathrm{~K}_{2} \mathrm{O} \mathrm{ha}^{-1}$ and $150 \mathrm{~kg}$ $\mathrm{K}_{2} \mathrm{O} \mathrm{ha}^{-1}$ doses. The highest dry weight of biomass was obtained in the treatment of $150 \mathrm{~kg} \mathrm{~K}_{2} \mathrm{O} \mathrm{ha}^{-1}$, i.e. $26.42 \mathrm{~g} \mathrm{clump}^{-1}$. Rauf (2000) indicates that the application of $\mathrm{K}$ fertilizer can increase biomass weight. The availability of $\mathrm{K}$ in soil can be absorbed by plants and adding $\mathrm{K}$ into plant tissue. K availability in soil affects plant rigidity, stimulates root growth and increases the number of tiller. Potassum fertilizer would enhance biomass weight. Mohiti et al. (2011) showed that potassium fertilization increases $\mathrm{K}$ uptake in rice and has an effect on increasing biomass weight.

\section{K Tissue}

Potassium is very important in plant physiological processes and generally needed in large quantity since $\mathrm{K}$ is essential in the formation of carbohydrate in plant. The results of Analysis of Variance indicates that the types of potassium fertilizers showed no significant effect on $\mathrm{K}$ tissue $(p=0.33)$. The results of DMRT showed that the $\mathrm{K}$ tissue in the treatments of $\mathrm{KCl}, \mathrm{ZK}$ and $\mathrm{KNO}_{3}$ fertilizers were not significantly different ( Figure $6 a)$. Figure $6 \mathrm{~b}$ showed that the application of $0 \mathrm{~kg}$ $\mathrm{K}_{2} \mathrm{O}$ ha $^{-1}$ resulted in $\mathrm{K}$ tissue of $1.77 \%$, which was not significantly different from that at $50 \mathrm{~kg} \mathrm{~K}_{2} \mathrm{O}$ ha $^{-1}$ treatment, i.e. $2.03 \%$. However, the K-tissue in both treatments were significantly different from that in $100 \mathrm{~kg} \mathrm{~K}_{2} \mathrm{O} \mathrm{ha}^{-1}$ and $150 \mathrm{~kg} \mathrm{~K}_{2} \mathrm{O} \mathrm{ha}^{-1}$ fertilizer treatments. The application of $100 \mathrm{~kg} \mathrm{~K}_{2} \mathrm{O} \mathrm{ha}^{-1}$ resulted in $\mathrm{K}$ tissue of $2.6 \%$, which was significantly different from that in the $150 \mathrm{~kg} \mathrm{~K}_{2} \mathrm{O} \mathrm{ha}^{-1}$ treatment, i.e. $3.21 \%$. Therefore, the application of potassium fertilizers at $150 \mathrm{~kg} \mathrm{~K}_{2} \mathrm{O} \mathrm{ha}^{-1}$ resulted in sufficient $\mathrm{K}$ tissue for plant growth. Potassium requirement for optimal plant growth is $2-5 \%$ of the dry weight (Marchner 1986); so in this study, the K tissue of rice plants is considered in the normal range for plant growth.

\section{K Uptake and its Efficiency}

Potassium is taken up by plants in the form of $\mathrm{K}^{+}$ion. Potassium uptake can be interpreted as the

Table 2. K uptake and efficiency in rice plants.

\begin{tabular}{lcc}
\hline Dose of potassium fertilizer & $\mathrm{K}$ uptake $\left(\mathrm{kg} \mathrm{ha}^{-1}\right)$ & $\mathrm{K}$ uptake efficiency (\%) \\
\hline $0 \mathrm{~kg} \mathrm{~K}_{2} \mathrm{O} \mathrm{ha}^{-1}$ & 60.8 & - \\
$50 \mathrm{~kg} \mathrm{~K}_{2} \mathrm{O} \mathrm{ha}^{-1}$ & 70.4 & 19.2 \\
$100 \mathrm{~kg} \mathrm{~K}_{2} \mathrm{O} \mathrm{ha}^{-1}$ & 97.6 & 36.8 \\
$150 \mathrm{~kg} \mathrm{~K}_{2} \mathrm{O} \mathrm{ha}^{-1}$ & 126.4 & 43.7 \\
\hline
\end{tabular}


Table 3. The corelation coefficients (r) obtained from the corelation tests between the soil and plant parameters.

\begin{tabular}{|c|c|c|c|c|c|c|c|c|}
\hline Parameter & $\begin{array}{c}\text { Plant } \\
\text { height }\end{array}$ & $\begin{array}{l}\text { Available K } \\
\text { (vegetative) }\end{array}$ & $\begin{array}{c}\text { Available K } \\
\text { (harvest) }\end{array}$ & CEC & $\begin{array}{l}\text { Dry weight } \\
\text { of biomass }\end{array}$ & $\begin{array}{c}\mathrm{K} \\
\text { tissue }\end{array}$ & $\begin{array}{c}\mathrm{K} \\
\text { uptake }\end{array}$ & $\begin{array}{c}\text { Base } \\
\text { saturation }\end{array}$ \\
\hline Plant height & & $0.35^{*}$ & $0.41^{*}$ & $0.47 * *$ & 0.03 & 0.33 & 0.24 & 0.96 \\
\hline $\begin{array}{l}\text { Avallable } \\
\text { (vegetative) }\end{array}$ & & & $0.57 * *$ & $0.39 *$ & 0.02 & $0.51 * *$ & $0.39 *$ & 0.26 \\
\hline $\begin{array}{l}\text { Available K } \\
\text { (harvest) }\end{array}$ & & & & $0.42 *$ & 0.09 & $0.53 * *$ & $0.42 *$ & 0.31 \\
\hline CEC & & & & & 0.26 & $0.58 * *$ & $0.57 * *$ & 0.22 \\
\hline $\begin{array}{l}\text { Dry weight of } \\
\text { biomass }\end{array}$ & & & & & & 0.34 & $0.63 * *$ & 0.10 \\
\hline $\mathrm{K}$ tissue & & & & & & & $0.90 * *$ & 0.24 \\
\hline $\begin{array}{l}\text { K uptake } \\
\text { Base } \\
\text { saturation }\end{array}$ & & & & & & & & 0.22 \\
\hline
\end{tabular}

Note : $* \mathrm{p}<0.05 ; * * \mathrm{p}<0.01$

process of transporting $\mathrm{K}^{+}$ion from soil solution into plant roots by mass flow or diffusion. Most potassium deficient plants exhibit weak symptoms in plant stems, causing plants to collapse easily (Rosmarkam and Yuwono 2002). The results of Analysis of Variance showed that the types of potassium fertilizers resulted in no significant effect on $\mathrm{K}$ uptake $(p=0.17)$, whereas doses of potassium fertilizers showed a significant effect on K uptake $(p=0.001)$. The results of DMRT showed that the K-uptake in the treatments of $\mathrm{KCl}, \mathrm{ZK}$ and $\mathrm{KNO}_{3}$ fertilizers were not significantly different (Figure $7 \mathrm{a}$ ).

The K-uptake in the control treatment (without potassium fertilization) was about 0.38 g clump $^{-1}$, which was not significantly different from that in the treatment of $50 \mathrm{~kg} \mathrm{~K}_{2} \mathrm{O} \mathrm{ha}^{-1}$, i.e. $0.44 \mathrm{~g} \mathrm{clump}^{-1}$ (Figure 7b). However, the K-uptake in both treatments were siginificatly different from that in the treatments of $100 \mathrm{~kg} \mathrm{~K}_{2} \mathrm{O} \mathrm{ha}^{-1}$ and 150 $\mathrm{kg} \mathrm{K}_{2} \mathrm{O} \mathrm{ha}^{-1}$. The $\mathrm{K}$-uptake in the treatment of 100 $\mathrm{Kg} \mathrm{K}_{2} \mathrm{O} \mathrm{ha}^{-1}$ was $0.61 \mathrm{~g} \mathrm{clump}^{-1}$, which was significantly different from that at $150 \mathrm{~K}_{2} \mathrm{O} \mathrm{ha}{ }^{-1}$, i.e. $0.79 \mathrm{~g}$ clump $^{-1}$. The highest $\mathrm{K}$ uptake was obtained in the application of $150 \mathrm{~K}_{2} \mathrm{O} \mathrm{ha}^{-1}$, which was about $0.79 \mathrm{~g} \mathrm{clump}^{-1}$ or $126.4 \mathrm{~kg} \mathrm{ha}^{-1}$ (Table 2), with an increase of $108 \%$ compared to that in the control treatment. The higher the dose of potassium fertilizers applied, the higher the availability of K, so the more $\mathrm{K}$ is taken up by plants.

According to Yuwono (2004), nutrient uptake efficiency (NUE) can be calculated using the following formula $=$

$$
\frac{(\mathrm{UT}-\mathrm{UC})}{\mathrm{NG}} \times 100 \%
$$

In which UT: nutrient uptake in fertilized plants (treatment), UC: nutrient uptake in plants without fertilization (control), NG: nutrient level derived from the amount of fertilizer applied.

Table 2 showed that the $\mathrm{K}$ uptake efficiency in the treatments of $50 \mathrm{~kg} \mathrm{~K}_{2} \mathrm{O} \mathrm{ha}^{-1}, 100 \mathrm{~kg} \mathrm{~K}_{2} \mathrm{O}$ $\mathrm{ha}^{-1}$ and $150 \mathrm{~kg} \mathrm{~K}_{2} \mathrm{O}^{-1}$ were $19.2 \%, 36.8 \%$ and $43.7 \%$, respectively. The higher the dose of potassium fertilizers applied, the higher the $\mathrm{K}$ uptake efficiency. Plants are still able to take up potassium following the dose applied, the higher the dose the higher the uptake. According to Tisdale et al. (1985), potassium is an element which can be over-absorbed (luxury consumption) by plants and so K availability is. As a result of excessive $\mathrm{K}$ uptake, it can disturb nutrient balance, especially $\mathrm{Ca}$ and $\mathrm{Mg}$.

\section{CONCLUSIONS}

The type of potassium fertilizers applied resulted in similar effects on almost all soil and plant parameters. The dose of potassium fertilizers significantly affected all soil and plant parameters, the higher the doses, the higher the values of the parameters observed.

The highest value of each parameter was reached at application of $150 \mathrm{~kg} \mathrm{~K} \mathrm{O} \mathrm{ha}^{-1}$. The average amount of available $\mathrm{K}$ in soil measured at the maximum vegetative growth of rice plants was $0.25 \mathrm{cmol}(+) \mathrm{kg}^{-1}$, the amount of available-K after harvest was $0.27 \mathrm{cmol}(+) \mathrm{kg}^{-1}, \mathrm{~K}$ uptake was 0.79 $\mathrm{g}$ clump $^{-1}$ and $\mathrm{K}$ uptake efficiency was $43.7 \%$.

\section{ACKNOWLEDGEMENTS}

We thank Sebelas Maret University for funding the research project. We thank the reviewers for their helpful comments to improve the manuscript. 


\section{REFERENCES}

Arifin Z. 2011. Analisis Nilai Indeks Kualitas Tanah Entisol pada Penggunaan Lahan yang Berbeda. Agroteksos 21: 47-54. (in Indonesian).

Damanik MMB, BE Hasibuan, Fauzi, Sarifuddin and H Hanum. 2011. Kesuburan Tanah dan Pemupukan. Medan: USU Press. (in Indonesian).

Eviati and Sulaeman. 2009. Petunjuk Teknis Analisis Kimia Tanah, Tanaman, Air dan Pupuk. Edisi kedua. Balai Penelitian Tanah. Bogor. 234 p.

Fitriadi A, Sufardi and Muyasir. 2012. Pengaruh Residu Pupuk KCl dan Kompos terhadap Sifat Kimia Tanah dan Pertumbuhan Padi (Oryza sativa L.). J Manajemen Sumberdaya Lahan 2: 223-230. (in Indonesian).

Jifu L, L Jianwei, L Xiaokun, R Tao, C Rihuan and Z Li. 2014. Dynamics of Potassium Release and Adsorption on Rice Straw Residue. Plos One 9: 1-10.

Marchner H. 1986. Mineral Nutrition in Height Plants.Academic Press. Harcourt Brace Jovanovich, Publisher. London. 254-267.

Mohiti, MM Ardalan, MA Torkashvand and HS Vahed. 2011. The Efficiency of Potassium Fertilization Methods on Growth of Rice (Oryza sativa L.) under Salinity Stress. Afr J Biot 10: 15946-15952. doi:10.5897/AJB11.1351.

Orcutt DM and ET Nilsen. 2000. The Physiology of Plants under Stress: Soil and Biotic Factors Vol.2. New Jersey: John Wiley and Sons Inc. 696p. ISBN: 9870471-17008-2.

Prajapati K and HA Modi 2012. The Importance of Potassium in Plant Growth. Indian J Plant Sci 1 (02-03): 2319-3824
RaufAW, Syamsuddin and SR Sihombing. 2000. Peranan Pupuk NPK pada Tanaman Padi. Irian Jaya: Departemen Pertanian Badan Penelitian dan Pengembangan Pertanian. Loka Pengkajian Pertanian Koya Barat Irian Jaya. (in Indonesian)

Rosmarkam A and NW Yuwono. 2002. Ilmu Kesuburan Tanah. Kanisius. Jakarta. (in Indonesian).

Sarief S. 1986. Ilmu Tanah Pertanian. Pustaka Buana. Bandung. (in Indonesian).

Singh VK, BS Dwivedi, RJ Buresh, ML Jat, K Majumdar, B Gangwar, V Govil and KS Susheel. 2013. Potassium Fertilization in Rice-Wheat System Across Northern India: Crop Performance and Soil Nutrients. Agronomy J 105: 471- 481.

Sudarsono. 2004. Peran Pupuk Pada Lahan Pertanian. Jakarta :Akasaraya. (in Indonesian).

Syarif RG, H Widijanto and Sumarno. 2013. Pengaruh dosis Imokulasi Azolla dan Pupuk Kalium Organik terhadap Ketersediaan $\mathrm{K}$ dan Hasil Padi pada Alfisol. J Ilmu tanah dan Agroteknologi 10: 63-73. (in Indonesian).

Tisdale SL, WL Nelson and JD Beaton. 1985. Soil Fertility and Fertilizers (fourth edition). Mac Millan publishing company. New York.

Utami SNH and S Handayani. 2003. Sifat Kimia Entisol pada Sistem Pertanian Organik. J Ilmu Pertanian 10: 63-69. (in Indonesian).

Utami NH. 2009. Kajian Sifat Fiik, Sifat Kimia dan Sifat Biologi Tanah Paska Tambang Galian C pada Tiga Penutup Lahan. IPB. Bogor. (in Indonesian).

Yuwono NW. 2004. Kesuburan Tanah. Universitas, Yogyakarta. (in Indonesian).

Zaman U, Z Ahmad, M Farooq, S Saeed, M Ahmad and A Wakeel. 2015. Potassium Fertilization may Improve Stem Strength and Yield of Basmati Rice Grown on Nitrogen-Fertilized Soils. Pak. J Agri Sci 52: 439-445. 